\title{
The Emergence of Phase Change Material in Solar Thermal Energy: A Scientometric Review
}

\author{
Muhammad Hussin Abdul Jabar, Norhuda Abdul Manaf*, Nor Ruwaida Jamian \\ Department of Chemical and Environmental Engineering, Malaysia-Japan International Institute of Technology
}

(MJIIT), Universiti Teknologi Malaysia, Kuala Lumpur, MALAYSIA

\begin{abstract}
Phase change material (PCM) features an attractive option due to its solar thermal storage capability to assist the cooling/heating process especially during night operation, thus contributing to the reduction of energy cost and carbon footprint. This study aims to analyse the emergence of PCM in the application of solar thermal energy. Subsequently, to envisage Technology Readiness Level (TRL) and commercialisation opportunity based on historical and contemporary research trends. This review encompasses of peer-reviewed literatures from Scopus database for one decade between 2010 and 2019. Based on the review, there is a moderate growth on the research related to PCMsolar thermal at $22 \%$ of emergence rate from the past one decade. China has dominated in this research development by concurring approximately $22 \%$ from the number of research articles published globally. It can be concluded that the application of PCM in solar thermal energy system is at TRL 5 which reflects research and development (R\&D) progress is at intermediate prototypical development based on the trend of academic publication. Furthermore, based on the review, PCM features great potential in commercialisation opportunity due to its vital contribution as a frontier material/substance in overcoming the challenges of energy and environmental insecurity.
\end{abstract}

Keywords: phase change material; solar thermal energy; renewable energy; LHTES

\section{INTRODUCTION}

Solar energy has been resilient through the Covid-19 crisis and its demand is expected to increase for the next few decades which may overtake coal as the primary means of producing electricity (IEA, 2020). Massive transformation to solar energy is a wise decision to enormously mitigate the global warming as well as carbon footprint. This scenario underlines that solar would be the future king of energy surpassing the traditional fossil fuel power generations.

At present, phase change material (PCM) emerges as an alternative approach to solar thermal energy storage. It can be used to mitigate the changes in energy demand between peak and off-peak periods. In solar energy storage, energy is transferred to the PCM in the form of latent and sensible heats. Between these two, latent heat thermal energy storage (LHTES) is more attractive and viable because of its high energy storage capacity in small volume with charging and discharging heat at constant temperature (Zeinelabdein et. al., 2018; Rathore et al., 2020). Essentially, many review articles have been published related to the hybrid thermal energy storage with PCM (LHTES). For instance, PCM material preparation and selection (Jiang et. al., 2019; Li et. al., 2019; Wang et. al., 2019; Asgharian \& Banisiadi, 2019), enhancement of PCM properties via nanomaterial (Badenhorst, 2019; Qiu et. al., 2019; Allahbakhsh \& Arjmand, 2019) encapsulation material of PCM (Liu et. al., 2018; Cárdenas-Ramírez et al., 2020) as well as process system engineering approach for hybrid thermal storage with PCM mechanism (Asgharian \& Baniasadi, 2019; Ehms et. al., 2019; Jiménez-Xamán et al., 2019). Contrary, this study aims to analyse the emergence of PCM in the application of solar thermal energy. Subsequently, to envisage Technology Readiness Level (TRL) and commercialisation opportunity based on historical and contemporary research trends. 


\section{MATERIALS AND METHOD}

Two analyses are conducted to meet the focus of this review paper. Bibliometric analysis of Scopus publication is used to predict PCM-emergence rate by assessing the growth of research publications. Similar scope of study has been done by Pandita et al. (2014) where they predicted the growth of research output at Indian medical research institutions. The emergence rate or annual growth rate is evaluated based on Equation 1, while identification of technology maturity (TRL) is performed based on the assessment of curated articles by determining the contemporary state of research (literature, laboratory, field testing (simulation), field testing (prototype) and commercial stages) and application trend.

$$
E r=\frac{\left(\left[\frac{E V}{B V}-1\right] * 100 \%\right)}{Y}
$$

Where, $E r$ is emergence rate or annual growth rate, $E V$ and $B V$ are the publication number in subsequent year and initial year respectively, while $Y$ is the number of years (period).

Additionally, this work also analysed recent research focus and country's involvement. For visualisation of research collaboration, VOSviewer software is used to create networking map for country co-authorship (Van Eck and Waltman, 2010).

\section{DISCUSSION}

\section{A. Bibliometric Analysis: Emerging Research Trend}

The emergence of PCM in the application of solar thermal energy is investigated via bibliometric analysis. This review involves scientometrics analysis on Scopus database from year 2010 until 2019 by combining the following keywords: "phase change material" and "solar thermal energy". A total of 2304 journal articles within the keywords are recapitulated as shown in Figure 1. From the number, approximately 10\% of them involved work related to literature review studies. While the remaining included research related to area of energy and PCM characteristic, laboratory/pilot-scales studies (design and application) and as well as modelling and simulation analysis based on various application area. Figure 1(a) illustrates that energy, engineering and material are the popular research areas in the PCM-solar thermal energy trend thus underpinning the significant of this work in exploring the research and technology evolution of PCM in solar thermal energy.
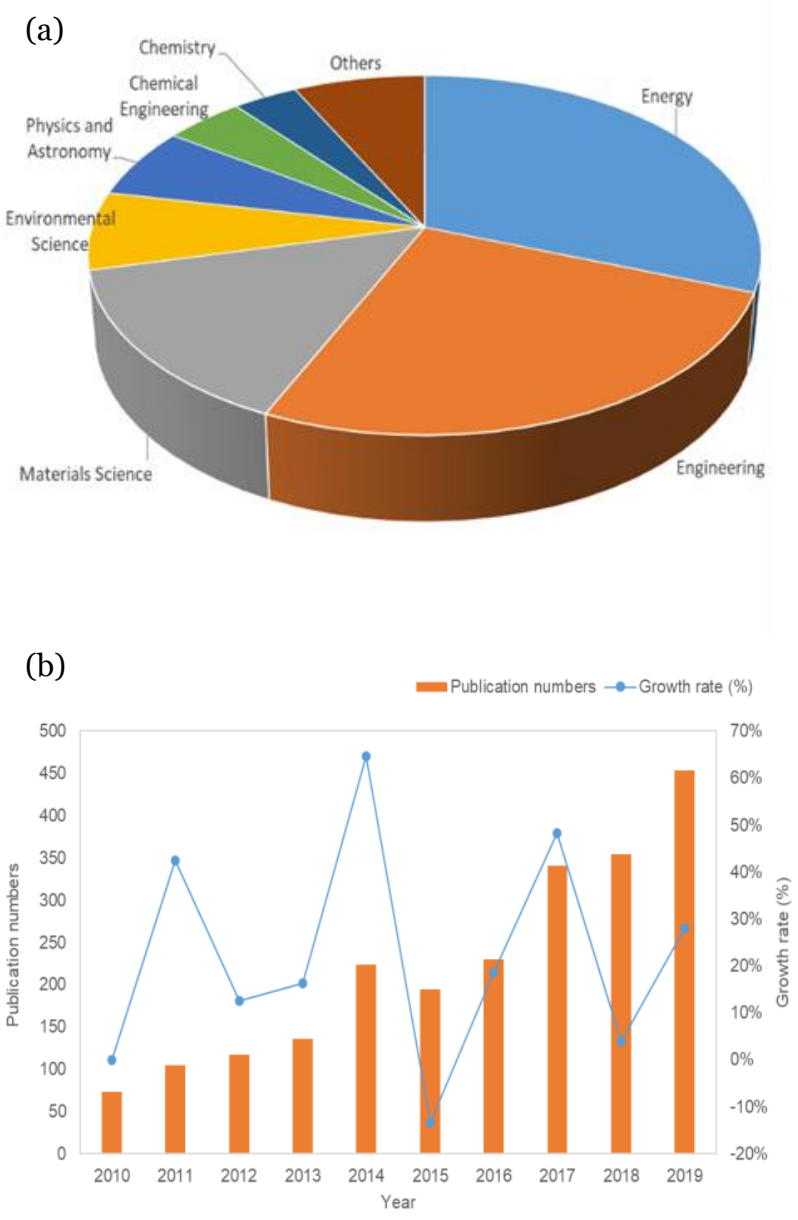

Figure 1. Research trend of journal articles published in Scopus database from year 2010 until 2019; (a) Research area/scope, and (b) Publication number.

In addition, there is moderate growth on the research related to PCM-solar thermal energy at average annual growth rate of $22 \%$ from the past decade as shown in Figure 1(b). It can be observed that the application of PCM-solar thermal energy in the global competitions first increased to the peak of $60 \%$ in 2014 and then decreased to less than $20 \%$ in the following years, before its continuous growth towards 2020. This annual growth demonstrates the emergence rate of PCM-solar thermal energy studies through the progression of publications numbers. Whereas it can be a vital indicator for the PCM potential in solar thermal energy application. 


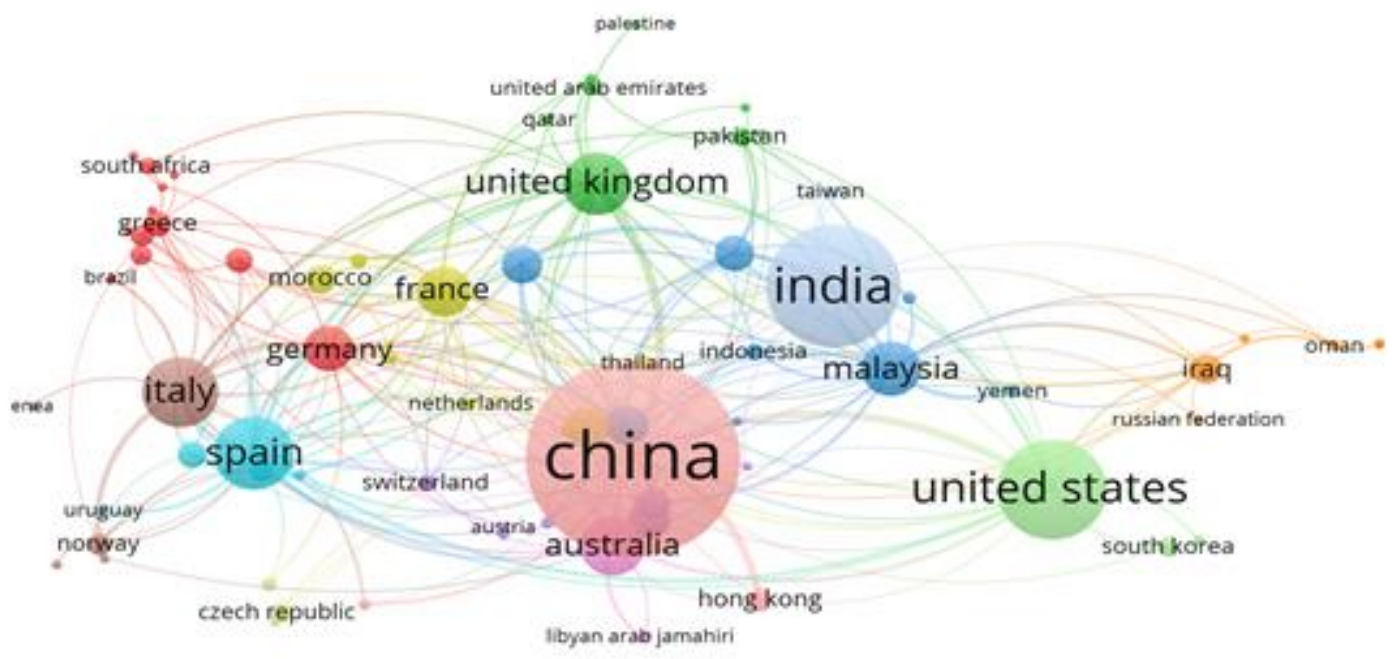

Figure 2. Network visualisation map of country co-authorships in PCM application in solar thermal energy research

From Figure 1(b), the PCM-research evolution spiked notably in year 2015 onwards with the major research focuses on energy and engineering. This is associated with the global demand towards mass utilisation of renewable energy to reduce dependency on fossil fuel, especially from International Agency. This circumstance may be influenced by the recent Paris Climate Agreement (UN, 2020) and 2030 Agenda for Sustainable Development Goal (UN, 2020) which resulted to the boosting of extensive research on PCM-solar thermal energy in recent years.

Figure 2 illustrates the collaboration network of countries who had at least five articles co-authorship. The thickness of lines indicates the strength of collaboration, and the node size signifies the number of publications of the country. Meanwhile, the colors represent the collaboration clusters. From the lines and nodes, China is dominating in this research exploration and produced major international collaborative research, follows by India and US. China has published the highest number of published articles accounted to 610 (22\% from the total publications), followed by India (281 publications) and US (248 publications). Interestingly, Malaysia is one of the emerging countries involved in the PCM-solar thermal energy studies thus underpinning the significant contribution of this work for Malaysian researchers. It can be noticed that PCM research has been gaining much attention specifically from countries with the highest population rate and rapid economic growth such as China, India and US (Countries in the world by population (2021), 2021).
From the networking map, three significant collaboration clusters can be distinguished; red cluster included China and Australia, blue cluster gathered Malaysia and India, and green cluster encompassed of US and UK. These clusters evident that research collaboratives activities were stimulated via region of influence. Please take note in this work, we only emphasised two significant countries for each cluster.

\section{B. Technology Readiness Level (TRL)}

Identification of technology readiness towards commercialisation is vital to academics involved in research, innovation and technology development (Setiawan et al., 2018). Essentially, TRL concept indicates maturity of specific technology which is reflected by Level 1 : Concept evaluation (Basic principle approved) to Level 9: Successful Deployment (Actual system proven in operational environment) as illustrated in Figure 3 (NASA, 2021; Martínez-Plumed et al., 2021). Few studies have been conducted to analyse the TRL such as in the food processing surfactant technology (Setiawan et al., 2018) and composite recycling technology (Rybicka et al., 2016). Nevertheless, to the best of author knowledge, there is no comprehensive analysis has been conducted in determining the TRL of PCM in thermal energy storage application. Thus, this work is significant not only to determine the contemporary research trend but to forecast the technology diffusion. Subsequently, to measure how much effort can be exerted in the context of academic perspective. 
Based on the Scopus database, there is a consistent et al., 2018), solar drying (Sandali et. al., 2019; Berville et. al., publication trend of literature review articles related to the 2019; Shalaby et al., 2014), solar collector (Zayed et. al., 2019; PCM-solar thermal energy storage such as in the application Khan et al., 2018), of photovoltaic (Ma et. al., 2019; Waqas et. al., 2018; Hasan

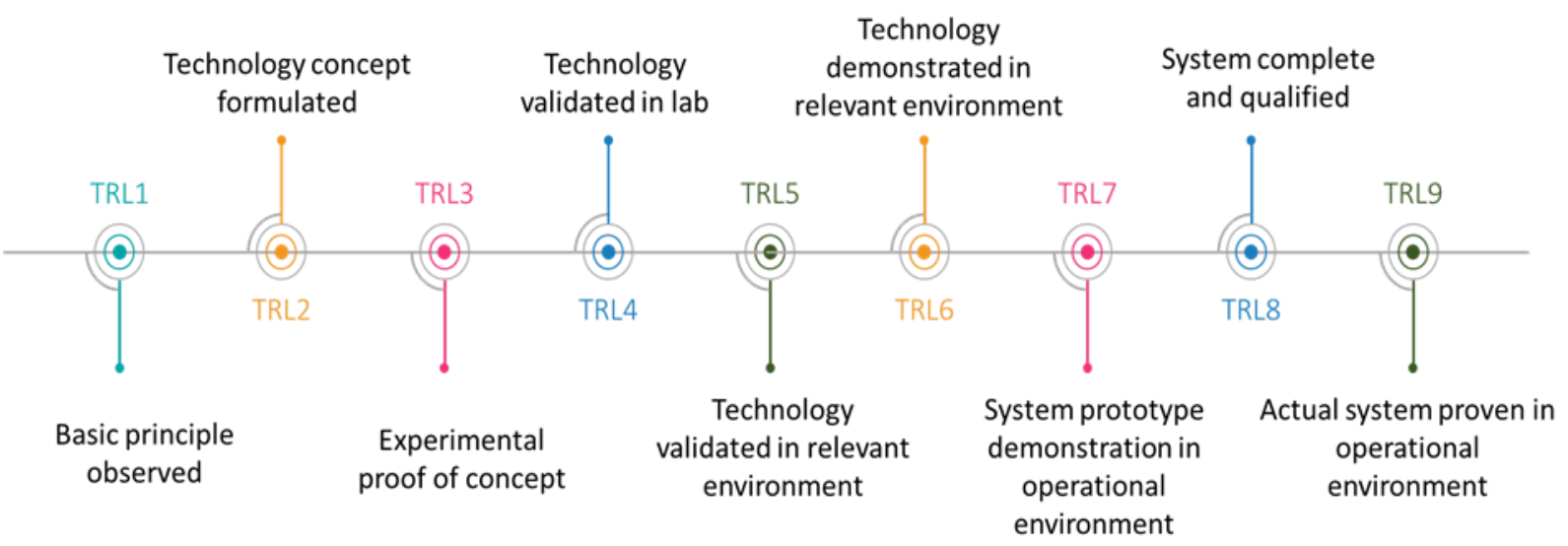

Figure 3. Technology Readiness Levels (TRLs) framework

solar air heater (Haldorai et al., 2019), and solar water heater (Kee et. al., 2018; Sadhishkumar \& Balusamy, 2014). Additionally, number of reviewed articles have been conducted related to the space heating, ventilation and cooling (HVAC) system (Ma et. al., 2019; Monghasemi \& Vadiee, 2018; Al-Abidi et al., 2012). This trend is due to the high demand pertains to sustainable and affordable thermal human comfort as discussed in (Yang \& Matzarakis, 2019; Mastrucci et al., 2019). Other reviews have been critically discussed for instance in term of PCM nanocomposite material (Qiu et. al., 2019; Allahbakhsh \& Arjmand, 2019; Jiang et. al., 2019; Arshad et. al., 2019; Dheep \& Sreekumar, 2014; Yuan et. al. , 2014; Yang et. al., 2019; Peng et al., 2018), PCM latent heat/thermal performance (Sarbu \& Dorca, 2019; Lin et. al., 2018; Fan \& Khodadadi, 2011) and PCM solar energy storage modelling and simulation (Asgharian \& Baniasadi, 2019; Jiménez-Xamán et. al., 2019; Ehms et al., 2019). These publication scenario (from the academic perspective) reflects moderate research/technology progress but feature an emerging potentiality via its high availability and visibility on the literature studies, where it was evident that the PCM-thermal energy storage studies have been surpassing TRL 2.

Referring to the Scopus database, an experimental setup of LHTES using two commercial PCMs (refine paraffin wax blend and fatty alcohol blend) coupled with solar collector for domestic hot water system has been developed by Dogkas et al. (2019). It was observed that fatty alcohol blend was able to return $79 \%$ of total energy used for charging process compared to refine paraffin wax, at $64 \%$. Back then, Calvet et al. (2011) employed a commercial latent heat storage composited with graphite for a prototype solar thermosiphon hot water system based on the experimental setup. It was proven that the addition of consolidated expanded natural graphite may enhance the thermal power up to $138 \%$ if compared to water (without graphite). Meanwhile, Desgrosseilliers et al. (2011) designed an LHTES (using lauric acid as the PCM) system coupled with a domestic hot water solar thermal system and was tested at apartment in Halifax, Canada. They found that utilisation of LHTES was able to store latent heat in less than 6 hours and withdraw within less than 3 hours, which exhibited a good performance of LHTES when integrated with hot water system.

Interestingly, PCM has been used as LHTES in laboratory/pilot prototypal stage since 2010. For instance, Bayón et al. (2010) developed a LHTES (using $\mathrm{KNO}_{3} / \mathrm{NaNO}_{3}$ as the PCM) prototype system integrated with actual solar thermal power plant for direct steam generation. Those prototype has been tested at the largest concentrating solar technology research located in Spain. It was indicated that the developed prototype was capable to store and deliver energy corresponding to $40 \mathrm{~kW}_{\text {th }}$ and $50 \mathrm{~kW}$ th, respectively. 
Nevertheless, it was unable to meet an actual prototype design which was at $100 \mathrm{Kw}_{\text {th. }}$ Rea et al. (2019) have designed a prototype system of LHTES (using Al-Si as the PCM) to convert thermal heat to electricity using Stirling engine. Their prototype was setup on top of the commercial solar power tower with ability to dis-integrate solar collection and electricity production. The system showed significant improvement in term of conversion efficiency at $18.5 \%$ during discharge period, which outperformed the existing studies conducted in the same field (Rea et. al., 2018; Elfeky et al., 2019).

A prototype design of solar assisted HVAC system driven by PCM in thermal energy storage has been initiated as early as 2012. Biswas et al. (2013) conducted field testing of prototype nano-PCM (composited with graphite) as interior wallboards to enhance energy efficiency for space heating and cooling for indoor thermal comfort. This has been tested at natural exposure test (NET) facility in United States. Goia et al. (2013) developed a glazing system (using RT35 paraffin as the PCM) system and embedded on the typical office building façade facility at TWINS - Testing Window Innovative System. Table 1 summarises several Scopus publications from 2019 until 2010 with the identification of TRL's range. This TRL identification was conducted based on the qualitative assessment and authors' prerogative subjected to the content of the articles. It can be concluded that TRL 5-7 is the most common stage of PCM-solar thermal storage research. This indicates that the research is still at the intermediate prototypical stage which requires further development, evaluation and investment for commercialisation.

Table 1. The TRL identification based on Scopus publications

\begin{tabular}{|c|c|c|c|c|}
\hline Ref & Type of PCMs & Application & TRL & $\begin{array}{l}\text { Location (if in the } \\
\text { related environment) }\end{array}$ \\
\hline Dogkas et al., 2019 & $\begin{array}{l}\text { Refine paraffin wax } \\
\text { blend and fatty alcohol } \\
\text { blend }\end{array}$ & $\begin{array}{l}\text { Domestic Hot water } \\
\text { system }\end{array}$ & $3-5$ & - \\
\hline Calvet et al., 2011 & $\begin{array}{l}\text { Water composited with } \\
\text { graphite }\end{array}$ & $\begin{array}{l}\text { Thermosiphon hot water } \\
\text { system }\end{array}$ & $3-5$ & - \\
\hline Desgrosseilliers et al., 2011 & Lauric acid & Domestic hot water solar & $5-7$ & $\begin{array}{l}\text { Apartment in Halifax, } \\
\text { Canada }\end{array}$ \\
\hline Çakmak \& Yildiz, 2011 & $\begin{array}{ll}\text { Calcium } & \text { chloride } \\
\text { hegzahidrat } & \end{array}$ & Solar dryer & $3-4$ & - \\
\hline Shalaby \& Bek, 2014 & paraffin wax & Solar dryer & $3-4$ & - \\
\hline Agarwal \& Sarviya, 2016 & paraffin wax & Solar dryer & $3-4$ & - \\
\hline El Khadraoui et al., 2017 & Paraffin & Solar dryer & $4-7$ & - \\
\hline Bayón et al., 2010 & $\mathrm{KNO}_{3} / \mathrm{NaNO}$ & $\begin{array}{l}\text { Dolar thermal power plant } \\
\text { for direct steam } \\
\text { generation }\end{array}$ & $6-8$ & Spain \\
\hline Rea et al., 2019 & $\mathrm{Al}-\mathrm{Si}$ & $\begin{array}{l}\text { Commercial solar power } \\
\text { tower }\end{array}$ & $6-8$ & - \\
\hline $\begin{array}{l}\text { Biaswas, Lu \& Soroushian, } \\
2013\end{array}$ & $\begin{array}{l}\text { Nano-PCM composited } \\
\text { with graphite }\end{array}$ & HVAC & $5-7$ & - \\
\hline Goia et al., 2013 & RT35 paraffin & HVAC & $5-7$ & United States \\
\hline Ma et al., 2016 & $\begin{array}{l}\text { RT24 and copper } \\
\text { nanoparticle }\end{array}$ & HVAC & $6-8$ & $\begin{array}{l}\text { Solar Decathlon (SD) } \\
\text { house, China }\end{array}$ \\
\hline Benli, 2011 & $\begin{array}{ll}\text { Calcium } & \text { chloride } \\
\text { hexahydrate } & \end{array}$ & HVAC & $5-7$ & - \\
\hline
\end{tabular}




\section{CONCLUSION}

Incorporation of PCM in thermal energy storage (also known as LHTES) has gained much attention due to its unique design and properties that are able to bridge the gap between energy supply and demand and deals with the diurnal pattern. Based on the Scopus database, there is moderate growth on the research related to PCM-solar thermal at $22 \%$ of emergence rate (annual growth) from the 2010 until 2019. Technology or research maturity was determined at TRL 5-7 which suggests that the research still requires further development, evaluation and investment for commercialisation. This preliminary technology review is solely based on prerogative and authors judgements based on the TRL framework available in (NASA, 2012; MartínezPlumed et al., 2021) and subjected to the content of published articles. One should take note that this review is totally based on database search which involves only academic articles though it does not capture other citation/peer-reviewed database such as Web of Science. However, validation from the experts and industrial point of view are required to support the shorthand evaluation of TRL. This present work is able to provide preliminary insight to the researchers and academics in current research portfolio of PCM especially in the application of solar thermal energy. Subsequently, to strategise the commercial development of PCM.

\section{ACKNOWLEDGEMENT}

This research is supported by MRUN Young Researchers Grant Scheme project no. R.K130000.7843.4L909 and R.K130000.7843.4L901.

\section{REFERENCES}

Agarwal, A \& Sarviya, R 2016, 'An experimental investigation of shell and tube latent heat storage for solar dryer using paraffin wax as heat storage material', Engineering Science and Technology, an International Journal, vol. 19, no. 1, pp. 619-631.

Al-Abidi, AA, Mat, SB, Sopian, K., Sulaiman, M, Lim, C \& Th, A 2012, 'Review of thermal energy storage for air conditioning systems', Renewable and Sustainable Energy Reviews, vol. 16, no. 8, pp. 5802-5819.

Allahbakhsh, A \& Arjmand, M 2019, 'Graphene-based phase change composites for energy harvesting and storage: state of the art and future prospects', Carbon, vol. 148, pp. 441480.

Arshad, A, Jabbal, M, Yan, Y \& Darkwa, J 2019, 'The micro/nano-PCMs for thermal energy storage systems: a state of art review', International Journal of Energy Research, vol. 43, no. 11 , pp. 5572-5620.

Asgharian, H \& Baniasadi, E 2019, 'A review on modeling and simulation of solar energy storage systems based on phase change materials', Journal of Energy Storage, vol. 21, pp. 186-201.

Badenhorst, H 2019, 'A review of the application of carbon materials in solar thermal energy storage', Solar Energy, vol. 192, pp. 35-68.
Bayón, R, Rojas, E, Valenzuela, L, Zarza, E \& León, J 2010, 'Analysis of the experimental behaviour of a $100 \mathrm{kWth}$ latent heat storage system for direct steam generation in solar thermal power plants', Applied Thermal Engineering, vol. 30 no. 17-18, pp. 2643-2651.

Benli, H 2011, 'Energetic performance analysis of a groundsource heat pump system with latent heat storage for a greenhouse heating', Energy Conversion and Management, vol. 52, no. 1, pp. 581-589.

Berville, C, Croitoru, CV \& Nastase, I 2019, 'Recent Advances in solar drying technologies- A short review': International Conference on Energy and Environment (CIEM), $23^{\text {rd }}$ September 2019, IEEE, Timisoara.

Biswas, K, LuPh D, J \& Soroushian, P 2013. 'Field testing of nano-PCM-enhanced building envelope components in a warm-humid climate': Thermal performance of the exterior envelopes of whole buildings XII, Florida, $1^{\text {st }}$ January 2013, US Department of Energy, United States.

Çakmak, G \& Yıldız, C 2011, 'The drying kinetics of seeded grape in solar dryer with PCM-based solar integrated collector', Food and Bioproducts Processing, vol. 89, no. 2, pp. 103-108.

Calvet, NJ, Py, X, Olives, R, Bedecarrats, JP, Dumas, JP \& Jay, F 2011, 'Enhancement of effective thermal conductivity in 
macro-encapsulate PCMs': Abstracts of Papers of The American Chemical Society, Washington, 28 ${ }^{\text {th }}$ August 2011, American Chemical Society, Washington.

Cárdenas-Ramírez, C, Jaramillo, F \& Gómez, M 2020, 'Systematic review of encapsulation and shape-stabilization of phase change materials', Journal of Energy Storage, vol. 30, pp. 101495 .

Countries in the world by population (2021), 2021, Worldometer, viewed 29 January 2021, $<$ https://www.worldometers.info/worldpopulation/population-by-country $>$.

Desgrosseilliers, L, Murray, R, Safatli, A, Marin, G, Stewart, J, Osbourne, N, White, MA \& Groulx, D 2011. 'Phase change material selection in the design of a latent heat energy storage system coupled with a domestic hot water solar thermal system': ASHRAE Annual Conference, Montreal, October 2011, Canada.

Dheep, GR \& Sreekumar, A 2014, 'Influence of nanomaterials on properties of latent heat solar thermal energy storage materials-A review', Energy Conversion and Management, vol. 83, pp. 133-148.

Dogkas, G, Konstantaras, J, Koukou, MK, Stathopoulos, VN, Coelho, L \& Rebola, A 2019, 'Evaluating a prototype compact thermal energy storage tank using paraffin-based phase change material for domestic hot water production': E3S Web of Conferences, 2019, EDP Sciences.

Ehms, JHN, Oliveski, RDC, Rocha, LAO, Biserni, C \& Garai, M 2019, 'Phase change materials (PCM) for building envelope applications: A review of numerical models': AIP Conference Proceedings, $17^{\text {th }}$ December 2019, AIP Publishing LLC.

El Khadraoui, A, Bouadila, S, Kooli, S, Farhat, A \& Guizani, A 2017, 'Thermal behavior of indirect solar dryer: Nocturnal usage of solar air collector with PCM', Journal of Cleaner Production, vol. 148, pp. 37-48.

Elfeky, K, Ahmed, N, Naqvi, S \& Wang, Q 2019, 'Numerical investigation of the melting temperature effect on the performance of thermocline thermal energy storage tank for CSP', Energy Procedia, vol. 158, pp. 4715-4720.

Fan, L \& Khodadadi, JM 2011, 'Thermal conductivity enhancement of phase change materials for thermal energy storage: a review'. Renewable and Sustainable Energy Reviews, vol. 15, no. 1, pp. 24-46.

Goia, F, Perino, M \& Serra, V 2013, 'Improving thermal comfort conditions by means of PCM glazing systems', Energy and Buildings, vol. 6o, pp. 442-452.
Haldorai, S, Gurusamy, S \& Pradhapraj, M 2019, 'A review on thermal energy storage systems in solar air heaters', International Journal of Energy Research, vol. 43, no. 12, pp. 6061-6077.

Hasan, A, Sarwar, J \& Shah, AH 2018, 'Concentrated photovoltaic: A review of thermal aspects, challenges and opportunities', Renewable and Sustainable Energy Reviews, vol. 94, pp. 835-852.

Jiang, Y, Liu, M \& Sun, Y 2019, 'Review on the development of high temperature phase change material composites for solar thermal energy storage', Solar Energy Materials and Solar Cells, vol. 203, pp. 110164.

Jiménez-Xamán, C, Xamán, J, Moraga, NO, HernándezPérez, I, Zavala-Guillén, I, Arce, J \& Jiménez, M 2019, 'Solar chimneys with a phase change material for buildings: An overview using CFD and global energy balance', Energy and Buildings, vol. 186, pp. 384-404.

Kee, SY, Munusamy, Y, \& Ong, KS 2018, 'Review of solar water heaters incorporating solid-liquid organic phase change materials as thermal storage', Applied Thermal Engineering, vol. 131, pp. 455-471.

Khan, MMA, Ibrahim, NI, Mahbubul, I, Ali, HM, Saidur, R \& Al-Sulaiman, FA 2018, 'Evaluation of solar collector designs with integrated latent heat thermal energy storage: a review', Solar Energy, vol 166, pp. 334-350.

Li, C, Li, Q, Zhao, Y, Cong, L, Jiang, Z, Li, Y \& Ding, Y 2019, 'Composite phase change materials for thermal energy storage: From molecular modelling based formulation to innovative manufacture', Energy Procedia, vol. 158, pp. 4510-4516.

Lin, Y, Jia, Y, Alva, G \& Fang, G 2018 'Review on thermal conductivity enhancement, thermal properties and applications of phase change materials in thermal energy storage', Renewable and Sustainable Energy Reviews, vol. 82, pp. 2730-2742.

Liu, Z, Yu, ZJ, Yang, T, Qin, D, Li, S, Zhang, G, Haghighat, F \& Joybari, MM 2018, 'A review on macro-encapsulated phase change material for building envelope applications', Building and Environment, vol. 144, pp. 281-294.

Ma, T, Li, Z \& Zhao, J 2019, 'Photovoltaic panel integrated with phase change materials (PV-PCM): technology overview and materials selection', Renewable and Sustainable Energy Reviews, vol. 116, pp. 109406.

Ma, Z, Ren, H \& Lin, W 2019, 'A review of heating, ventilation and air conditioning technologies and innovations used in solar-powered net zero energy Solar Decathlon houses', Journal of Cleaner Production, vol. 240, pp. 118158. 
Ma, Z, Lin, W \& Sohel, MI 2016, 'Nano-enhanced phase change materials for improved building performance', Renewable and Sustainable Energy Reviews, vol. 58, pp. 1256-1268.

Martínez-Plumed, F, Gómez, E \& Hernández-Orallo, J 2021, 'Futures of artificial intelligence through technology readiness levels', Telematics and Informatics, vol. 58, pp. 101525 .

Mastrucci, A, Byers, E, Pachauri, S \& Rao, ND 2019, 'Improving the SDG energy poverty targets: Residential cooling needs in the Global South', Energy and Buildings, vol. 186, pp. 405-415.

Monghasemi, N \& Vadiee, A 2018, 'A review of solar chimney integrated systems for space heating and cooling application', Renewable and Sustainable Energy Reviews, vol. 81, pp. 2714-2730.

NASA (The National Aeronautics and Space Administration) 2012, Technology Readiness Level, NASA, viewed 29 January

2021,

<https://www.nasa.gov/directorates/heo/scan/engineerin $\mathrm{g} /$ technology/txt accordion1.html $>$.

Pandita, R, Singh, S \& Gaur, R 2014, 'Research output of some selected Indian medical research institutions (2007-2011)', University of Nebraska-Lincoln, DigitalCommons, Library Philosophy and Practice.

Peng, H, Zhang, D, Ling, X, Li, Y, Wang, Y, Yu, Q, She, X, Li, Y \& Ding, Y 2018, 'n-Alkanes phase change materials and their microencapsulation for thermal energy storage: a critical review', Energy \& Fuels, vol. 32, no. 7, pp. 72627293.

Qiu, L, Ouyang, Y, Feng, Y \& Zhang, X 2019, 'Review on micro/nano phase change materials for solar thermal applications', Renewable Energy, vol. 140, pp. 513-538.

Rathore, PKS, Shukla, SK \& Gupta, NK 2020, 'Potential of microencapsulated PCM for energy savings in buildings: A critical review', Sustainable Cities and Society, vol. 53, pp. 101884 .

Rea, JE, Oshman, CJ, Singh, A, Alleman, J, Buchholz, G, Parilla, PA, Adamczyk, JM, Fujishin, HN, Ortiz, BR \& Braden, T 2019, 'Prototype latent heat storage system with aluminum-silicon as a phase change material and a Stirling engine for electricity generation', Energy Conversion and Management, vol. 199, pp. 111992.

Rybicka, J, Tiwari, A \& Leeke, GA 2016, 'Technology readiness level assessment of composites recycling technologies', Journal of Cleaner Production, vol. 112, pp. 1001-1012.
Sadhishkumar, S \& Balusamy, T 2014, 'Performance improvement in solar water heating systems-A review', Renewable and Sustainable Energy Reviews, vol. 37, pp. 191-198.

Sandali, M, Boubekri, A \& Mennouche, D 2019, 'Improvement of the thermal performance of solar drying systems using different techniques: a review', Journal of Solar Energy Engineering, vol. 141, no. 5 .

Sarbu, I \& Dorca, A 2019, 'Review on heat transfer analysis in thermal energy storage using latent heat storage systems and phase change materials', International Journal of Energy Research, vol. 43, no. 1, pp. 29-64.

Setiawan, AAR, Sulaswatty, A, Meliana, Y \& Haryono, A 2018, 'Innovation readiness assessment toward research commercialization: case of surfactants for food processing', International Journal of Innovation, vol. 6, no. 2, pp. 180193.

Shalaby, S \& Bek, M 2014, 'Experimental investigation of a novel indirect solar dryer implementing PCM as energy storage medium', Energy Conversion and Management, vol. 83, pp. 1-8.

Shalaby, S, Bek, M \& El-Sebaii, A 2014, 'Solar dryers with PCM as energy storage medium: A review', Renewable and Sustainable Energy Reviews, vol. 33, pp. 110-116.

UN (United Nations), The Paris Agreement, UN, viewed on 9 November 2020, <https://unfccc.int/process-andmeetings/the-paris-agreement/the-paris-agreement $>$.

Van Eck, NJ \& Waltman, L 2010, 'Software survey: VOSviewer, a computer program for bibliometric mapping', Scientometrics, vol. 84, no. 2, pp. 523-538.

Wang, F, Lin, W, Ling, Z \& Fang, X 2019, 'A comprehensive review on phase change material emulsions: Fabrication, characteristics, and heat transfer performance', Solar Energy Materials and Solar Cells, vol. 191, pp. 218-234.

Waqas, A, Ji, J, Xu, L, Ali, M \& Alvi, J 2018, 'Thermal and electrical management of photovoltaic panels using phase change materials-A review', Renewable and Sustainable Energy Reviews, vol. 92, pp. 254-271.

Yang, G, Yim, YJ, Lee, JW, Heo, YJ \& Park, SJ 2019, 'Carbonfilled organic phase-change materials for thermal energy storage: A review', Molecules, vol. 24, no. 11, pp. 2055.

Yang, SQ \& Matzarakis, A 2019, 'Implementation of human thermal comfort and air humidity in Köppen-Geiger climate classification and importance towards the achievement of sustainable development goals', Theoretical and Applied Climatology, vol. 138, no. 1, pp. 981-998. 
Yuan, Y, Zhang, N, Tao, W, Cao, X \& He, Y 2014, 'Fatty acids as phase change materials: a review', Renewable and Sustainable Energy Reviews, vol. 29, pp. 482-498.

Zayed, ME, Zhao, J, Elsheikh, AH, Hammad, FA, Ma, L, Du, Y, Kabeel, AE \& Shalaby, S 2019, 'Applications of cascaded phase change materials in solar water collector storage tanks: A review', Solar Energy Materials and Solar Cells, vol. 199, pp. 24-49.

Zeinelabdein, R, Omer, S \& Gan, G 2018, 'Critical review of latent heat storage systems for free cooling in buildings', Renewable and Sustainable Energy Reviews, vol. 82, pp. 2843-2868. 